İŞLETME ARAŞTIRMALARI DERGİSI
JOURNAL OF BUSINESS RESEARCH-TURK
2019, 11(2), 1044-1056
https://doi.org/10.20491/isarder.2019.654

\title{
Is Cultural Environment a Determinant of Perceived Corporate Reputation?
}

\author{
Volkan YÜNCÜ iDa Celil KOPARAL iDb \\ a Afyon Kocatepe University, Afyon, Turkey. vyuncu@aku.edu.tr \\ b Anadolu University, Eskişehir, Turkey. ckoparal@anadolu.edu.tr
}

\begin{tabular}{|c|c|}
\hline ARTICLE INFO & ABSTRACT \\
\hline Keywords: & Purpose - The purpose of this study is to determine the factors that consumers prioritize in the \\
\hline Corporate Reputation & formation process of the organizational reputation perception and to determine the superiority of \\
\hline Perceived Reputation & $\begin{array}{l}\text { these factors to each other. Within this context, this study aims to bring a new and a cross-cultural } \\
\text { perspective to the way organizational reputation is managed for today's managers. }\end{array}$ \\
\hline AHP & Design/methodology/approach - The superiority of the factors that constitute the organizational \\
\hline Cross-Cultural Management & reputation with each other is determined at the factor and item level by using AHP (Analytic \\
\hline $\begin{array}{l}\text { Multiple-Criteria Decision Making } \\
\text { Methods }\end{array}$ & $\begin{array}{l}\text { Hierarchy Process) method. Since the research is carried out in two different cultures, it has two } \\
\text { different study population and samples. In this sense, the perception of the reputation of two } \\
\text { different cultural groups (in Turkey and Germany) was compared, and the main variables shaping } \\
\text { this perception and the attributed importance were determined comparatively. }\end{array}$ \\
\hline Received 3 January 2019 & $\begin{array}{l}\text { Findings - As a result, it has been determined that the main variables that constitute the } \\
\text { perception of reputation of different cultural groups show significant differences between the two }\end{array}$ \\
\hline Revised 1 April 2019 & $\begin{array}{l}\text { perception of reputation of different cultural groups show significant differences between the two } \\
\text { cultures. In addition, it was concluded that the scale used in the study could be implemented using }\end{array}$ \\
\hline Accepted 3 May 2019 & only 7 items instead of 23 items, which would provide great convenience in terms of time and cost \\
\hline Article Classification: & for future research. \\
\hline Research Article & $\begin{array}{l}\text { Discussion - The results of the research provide the basis for new and original research topics for } \\
\text { future studies. Investigation of the effects of cultural differences or the effects of demographic } \\
\text { variables on the perception of organizational reputation will contribute significantly. Also, we } \\
\text { suggest that the original scale used in the study be applied with } 7 \text { items in similar studies and it } \\
\text { would be useful to evaluate the obtained results. }\end{array}$ \\
\hline
\end{tabular}

\section{Introduction}

Reputation is a construct that has gained widespread recognition in the disciplines of strategy, corporate social responsibility, management and marketing (Dowling, 2016). In the first studies on corporate reputation, the dominance of marketing and communication sciences is clear. Today, however, the concept is now being dealt under the title of strategic management, human resources management and corporate strategy via an interdisciplinary integration. It is widely accepted that corporate reputation starts from inside and is transmitted to outside. Reputation of an organization is conveyed through internal environment elements. A large number of researches indicate that corporate identity and reputation, which are critical assets, have a key role to gain competitive advantage that will eventually contribute to making more profits (Chahal and Kumari, 2014; Gardner and Fombrun, 2002). Furthermore, with respect to the link between reputation and business benefits, empirical research has provided an abundance of evidence indicating that a firm's reputation influences organizational performance (Dane, 2018). This indicates that managers' strategic vision should acknowledge outsiders' perceptions of the organization when establishing their aspirations for the organization's future (De Roeck et al.,2013: Hatch and Schultz, 2003). The interplay of an organization's strategic vision, culture and reputation provides the foundation for building a successful and attractive corporate brand that fosters stakeholders' perceptions of belongingness with the organization future (De Roeck et al.,2013. Particularly in the context of strategic management, the literature on resource dependency approach suggests that sustainable competitive advantage can be achieved with abstract features and abilities that include brand and reputation (Omar and Lingelbach, 2009) asserting that a well-established corporate

*This study is derived from Volkan Yuncu's doctoral dissertation entitled "Cultural Effects on Consumer Perception of Corporate Reputation" in the Department of Management and Organization, Institute of Social Sciences, Anadolu University. The dissertation was completed in consultation with Prof. Dr. Celil Koparal, and was supported by Anadolu University BAP with the project number $1602 E 059$. 
reputation provides significant competitive advantage to organizations in terms of innovation, productivity, intellectual capital, high service level or quality. There is an increasing acceptance regarding the importance of reputation, a hot agenda item for both academia and business, as a strategic value and its impact on corporate strategy success. However, academicians are still striving to draw the boundaries of the concept precisely. A number of definitions, and conceptualizations studies that confront the study of the literature in the context of the management literature show that the concept is, in fact, surprisingly more complex than it was initially considered to be (Lange et al., 2011). In this regard, Dowling and Gardberg (2012) examined 30 measurements in 50 different countries, and Walker (2010) examined 54 articles with the most references, Inglis et al. (2006) developed a single econometric analysis by reducing the four dimensional measure to a single factor, while Groenland (2002) found that the factors used to measure reputation were significantly influenced by emotional dimensions. The conclusion to be drawn from the sum of these studies is that the reputation is an intuitive emotional reaction which is difficult to rationalize and disclose qualitatively, statistically and conceptually (Zarkada and Polydorou, 2013: 89).

\section{Theoretical Framework}

Walker (2010) has developed a three-stage theoretical model based on three basic theories to avoid a theoretical confusion and superficiality in his work on a systematic literature search. These three theories are methodologically focused on different stages of reputation. More precisely, institutional theory deals with the initial processes of establishing a positive corporate reputation. Signaling theory focuses on the signals that are conveyed to stakeholders and the way these signals are perceived. Finally, the resource dependency approach embraces the outputs of corporate reputation within the scope of achieving competitive advantage.

\subsection{Institutional Theory and Reputation}

The institutionalists argue that there are norms and organizational patterns outside the organization that determine how to structure and manage the organization (Duman, 2000; Newman, 2000). In general, this approach draws attention to the influence of established rules, values and norms by emphasizing the social and cultural environment in the form of organizational arrangements (DiMaggio, 1991). The main reason for the acceptance of the institutional theory paradigm as a general theory of culture is, therefore, this basic approach of the theory. Indeed, culture has been a topic of interest since the writings of early Greek scholars (Patel,2017: Gelfand et al., 2007) though business scholars have made significant advances in recent times toward understanding culture and its impact on business-related outcomes (Patel,2017: Taras et al., 2009). Hence, institutional theory focuses on the operational level in a context where reputation is constructed from scratch and how organizations acquire legitimacy as well as how they can benefit from the institutional context (Walker 2010; Deephouse and Carter, 2005; Rao, 1994). Accordingly, organizations must adhere to their own corporate context in order to be legitimate as it can bring in a competitive advantage which can be applied across the world in other markets to obtain significant benefits (Márquez and Pedeuga, 2017). However, these organizations may become structurally isomorphous since they have to conform to similar institutions independent from their rational needs peculiar to them (Sargut and Özen, 2010).

\subsection{Signaling Theory and Reputation}

Signaling theory (Spence,1973) is used to explain the strategic signals and images that businesses and stakeholders send to each other. Under the framework of this theory, how the strategic actions of businesses turns into signals and how these signals are interpreted by stakeholders are discussed (Sumer and Pernsteiner, 2014) as signals enable firms to convey its true quality to investors. Powerful signals create a 'separating equilibrium', meaning that pursuing a signaling strategy assures maximum payoffs only for the high-quality firm (Deb, 2013). At this point, the influence of the cultural structure, which contains the stakeholder groups, on interpretation is of particular importance. Signal theorists draw our attention to the content of reputation as information. In literature, especially economists have defined reputation as a signal and trait, and they have examined the notion through the perceptions of external stakeholders of a certain organization. According to signaling theorists, reputation is informational signals that help organizations build trust in their products and services. In fact, the main field of investigation of signaling theory is the reduction of information asymmetry between the organization and its stakeholders. It is a useful approach to describe the behaviors of these actors when two parties have access to different information Typically, one party, the sender, must choose whether and how to signal that information, and the other party, the receiver, must choose how to interpret the signal (Connelly et al. 2011). Signal theorists treat the social performance of an organization in 
terms of social responsibility as a variable that affects its reputation (Sumer and Pernsteiner, 2014).

\subsection{Resource Dependency Theory and Reputation}

Fundamentally, this theory explains the variation in performance between firms by a firm's unique resource bundles which are rare, valuable, costly to imitate, and non-substitutable and so create a competitive advantage (Sirsly and Lvina, 2016; Barney, 1991, 2001;). Since corporate reputation is regarded as a valuable resource that businesses can use to achieve both financial and non-financial benefits (Radomir et al. 2014), it is discussed in the scope of the theory of resource dependence as well. Particularly, in the context of strategic management, the literature on resource dependency approach suggests that sustainable competitive advantage can be achieved with intangible assets and abilities including brand and reputation (Omar and Lingelbach, 2009). Thus, reputation is one corporate intangible asset or a nonphysical strategic asset (Corsino, M. and Passarelli, M., 2009) that is thought to enhance customer satisfaction and loyalty, employee attraction and retention, firm equity, and investor awareness (Gottschalk, 2011).

\section{Research}

\subsection{Research Model}

In this survey, the reputation measurement scale of Fombrun et al. (2015) was utilized based on the importance levels of seven factors and 23 items. After the pre-test phase consisting of two pilot studies, the research process was started in two different cultures (Turkey-Germany) consecutively. Focus group study was preferred as the method in the pre-test process since the focus groups help to reveal variability in the appearance and formality of the questionnaire, the appropriateness of the answer choices, the language used and the interpretation of the questions (Altunışık, 2008). Following the pre-test phase consisting of two pilot studies with a sample size of 100 participants for each sample, the survey was conducted in two different cultures (Afyonkarahisar and Augsburg cities).

\subsubsection{Methodology}

The research is designed on the basis of the Analytical Hierarchy Process method (Applied in Matlab) which is a decision making technique that measures all objective and subjective criteria by making binary comparisons and determines the priority order of these criteria by comparing them to each other (Göksu and Güngör, 2008; Byun,2001). The AHP, which was first used as a probability calculation technique, is a multivariate decision making technique that was introduced by L. Thomas Saaty in 1965 though its theoretical maturation is accepted to to be realized only in the 1970s. As a problem-solving technique, it is possible to say that the AHP operates on three basic principles: decomposition in a linear process, comparative evaluation and synthesis of priorities. Hence, the first step in the implementation process in this study consists of defining a decision making problem. The data obtained after defining the decision problem are standardized on the basis of the Saaty (2008) significance values given in Table 1 and the power ratios against each other are calculated. Then a matrix of factorial comparison was established. Finally, the importance distributions of the factors have been determined. The sub-steps to be followed when these processes are performed are given below. The mathematical formula used when constructing decision matrices for subcriteria and factors is as follows:

$$
\mathrm{A}=\left[\begin{array}{ccccc}
a_{11} & a_{12} & a_{13} & \ldots & a_{1 n} \\
a_{21} & a_{22} & a_{23} & \ldots & a_{2 n} \\
\vdots & \vdots & \vdots & \cdots & \vdots \\
\vdots & \vdots & \vdots & \cdots & \vdots \\
a_{n 1} & a_{n 2} & a_{n 3} & \cdots & a_{n n}
\end{array}\right]
$$

In the comparison matrix, when $\forall_{\mathrm{i}, \mathrm{j}}$ for $i=j$, a a aij $=1$.

Because there 7 factors and 23 sub-items of these factors in the scale, the mean responses of 7 factors were obtained by taking the geometric mean of the sub-items in the scale obtained from the participants. The size of the composed matrix is $400 \times 7$ and this data is defined as the decision matrix. Here, taking geometric mean is directly related to the method and design of the research as geometric mean is used when the proportional differences between observational results in statistical studies are more important than absolute differences. 
Table 1. Saaty Values

\begin{tabular}{|l|l|l|}
\hline $\begin{array}{l}\text { Intensity of } \\
\text { Importance }\end{array}$ & Definition & Explanation \\
\hline 1 & $\begin{array}{l}\text { Equal } \\
\text { Importance }\end{array}$ & Two activities contribute equally to the objective \\
\hline 3 & $\begin{array}{l}\text { Moderate } \\
\text { importance }\end{array}$ & Experience and judgement slightly favour one activity over another \\
\hline 5 & $\begin{array}{l}\text { Strong } \\
\text { importance }\end{array}$ & Experience and judgement strongly favour one activity over another \\
\hline 7 & $\begin{array}{l}\text { Very strong or } \\
\text { demonstrated } \\
\text { importance }\end{array}$ & $\begin{array}{l}\text { An activity is favoured very strongly over another; its dominance } \\
\text { demonstrated in practice }\end{array}$ \\
\hline 9 & $\begin{array}{l}\text { Extreme } \\
\text { importance }\end{array}$ & $\begin{array}{l}\text { The evidence favouring one activity over another is of the highest } \\
\text { possible order of affirmation }\end{array}$ \\
\hline $2,4,6,8$ & $\begin{array}{l}\text { Intermediate } \\
\text { Values }\end{array}$ & Intermediate Values \\
\hline
\end{tabular}

Source: Thomas L. Saaty, 2008

The mutual significance levels of the factors are shown in a hierarchy frame. However, in order to determine the weights of the factors in the total data set, (in other words the percentage significance distributions) the mathematical operation is performed using the column vectors constituting the comparison matrix. In the last stage, column vector B is generated:

$$
\mathrm{B}=\left[\begin{array}{c}
b_{11} \\
b_{21} \\
\vdots \\
\vdots \\
b_{n 1}
\end{array}\right]
$$

The following formulas are used in the calculation of B column vectors:

$$
\mathrm{b}_{\mathrm{ij}}=\frac{a_{i j}}{\sum_{i=1}^{n} a_{i j}}
$$

Each $\mathrm{B}$ column vector is combined in a matrix format to obtain the matrix $\mathrm{C}$ given below.

$$
\begin{gathered}
\mathrm{C}=\left[\begin{array}{ccccc}
c_{11} & c_{12} & c_{13} & \ldots & c_{1 n} \\
c_{21} & c_{22} & c_{23} & \ldots & c_{2 n} \\
\vdots & \vdots & \vdots & \cdots & \vdots \\
\vdots & \vdots & \vdots & \cdots & \vdots \\
c_{n 1} & c_{n 2} & c_{n 3} & \cdots & c_{n n}
\end{array}\right] \\
\mathrm{w}_{\mathrm{i}}=\frac{\sum_{j=1}^{n} c_{i j}}{n}
\end{gathered}
$$

Calculated $\mathrm{w}$ values and $\mathrm{W}$ (weight) column matrix are obtained.

$$
\mathrm{W}=\left[\begin{array}{c}
w_{11} \\
w_{21} \\
\vdots \\
\vdots \\
w_{n 1}
\end{array}\right]
$$

The CR (Consistency rate) is based on a comparison of the number of factors and the $\lambda$ basic value. The steps of this calculation are given below. 


$$
\mathrm{D}=\left[\begin{array}{ccccc}
a_{11} & a_{12} & a_{13} & \ldots & a_{1 n} \\
a_{21} & a_{22} & a_{23} & \ldots & a_{2 n} \\
\vdots & \vdots & \vdots & \cdots & \vdots \\
\vdots & \vdots & \vdots & \cdots & \vdots \\
a_{n 1} & a_{n 2} & a_{n 3} & \cdots & a_{n n}
\end{array}\right] \times\left[\begin{array}{c}
w_{11} \\
w_{21} \\
\vdots \\
\vdots \\
w_{n 1}
\end{array}\right]
$$

By the ratio of the generated matrix $D$ to the weight matrix $W$, basic value (E) of each evaluation factor is found.

$$
\begin{gathered}
E_{i}=\frac{d_{i}}{w_{i}}, \quad \quad(i=1,2, \ldots, n) \\
\lambda=\frac{\sum_{i=1}^{n} E_{i}}{n}
\end{gathered}
$$

By taking the average of the values found, the basic value of the comparison is obtained. This is called the basic value $(\lambda)$. All of these stages are basically performed to obtain the CR (Consistency rate) coefficient. In this context, the Consistency Indicator (CI) is calculated by using the following formulas after the $\lambda$ value is calculated.

$$
\begin{gathered}
C I=\frac{\lambda-n}{n-1} \\
C R=\frac{C I}{R I}
\end{gathered}
$$

Table 2. RI values

\begin{tabular}{|c|c|c|c|c|c|}
\hline $\mathbf{N}$ & $\mathbf{R I}$ & $\mathbf{N}$ & $\mathbf{R I}$ & $\mathbf{N}$ & $\mathbf{2 1}$ \\
\hline $\mathbf{1}$ & 0 & $\mathbf{1 1}$ & 1.5141 & $\mathbf{2 1}$ & 1.6470 \\
\hline $\mathbf{2}$ & 0 & $\mathbf{1 2}$ & 1.5365 & $\mathbf{2 2}$ & 1.6526 \\
\hline $\mathbf{3}$ & 0.5245 & $\mathbf{1 3}$ & $\mathbf{2 3}$ & $\mathbf{2 4}$ & 1.6577 \\
\hline $\mathbf{4}$ & 0.8815 & $\mathbf{1 4}$ & 1.5713 & $\mathbf{2 5}$ & 1.6624 \\
\hline $\mathbf{5}$ & 1.1086 & $\mathbf{1 5}$ & $\mathbf{1 6}$ & $\mathbf{2 6}$ & 1.6667 \\
\hline $\mathbf{6}$ & 1.2479 & $\mathbf{1 6}$ & 1.5978 & $\mathbf{2 7}$ & 1.6706 \\
\hline $\mathbf{7}$ & 1.3417 & $\mathbf{1 8}$ & 1.6181 & $\mathbf{2 8}$ & 1.6743 \\
\hline $\mathbf{8}$ & 1.4056 & $\mathbf{1 9}$ & 1.6265 & $\mathbf{2 9}$ & 1.6777 \\
\hline $\mathbf{9}$ & 1.4499 & $\mathbf{2 0}$ & 1.6341 & $\mathbf{3 0}$ & 1.6809 \\
\hline $\mathbf{1 0}$ & 1.4854 & & & & \\
\hline
\end{tabular}

Source: Alonso and Lamata, 2006

As a result, the CR (Consistency rate) obtained according to Alonso and Lamata (2006) rates given in table 2, means that the results of the factor compared with the researcher's AHP method are consistent if the value is less than 0.10 . Otherwise, it means that the results obtained are inconsistent or there is a calculation error. 


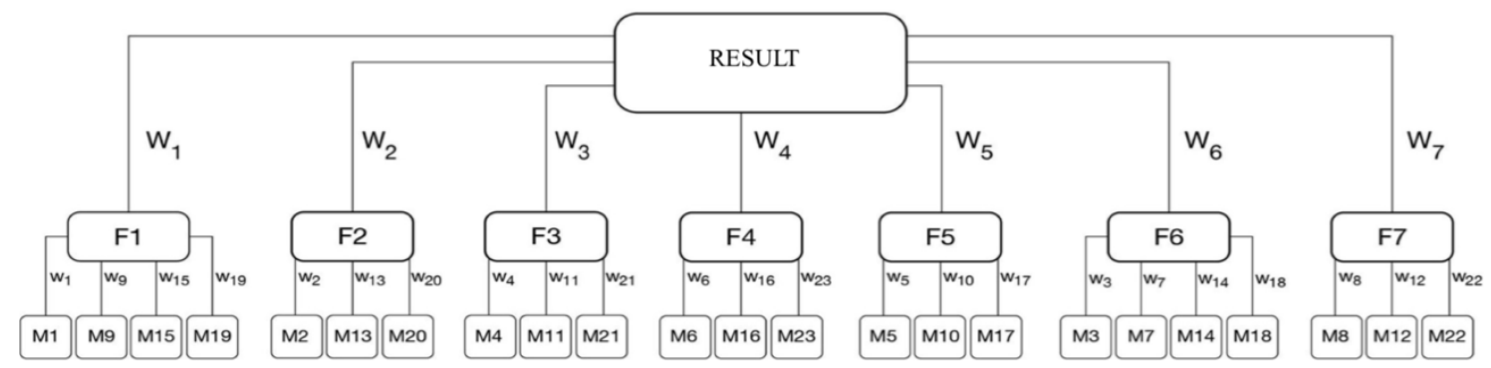

Figure 1. Research model

\subsection{Data Analysis and Findings}

\subsubsection{Adjusting Data to Saaty Scale}

Table 3 shows the power percentages (weights) of the 7 main factors through which the reputation perception was measured in the study were determined via the AHP method. Seven major factors (alternatives) and 23 items (criteria) were considered in the study. In this context, firstly the answers given to the questionnaire were converted into quantitative data and the comparison matrix of 23 items was calculated.

Table 3. Weights of each item in Turkey and Germany

\begin{tabular}{|l|l|l|l|l|l|l|l|l|l|l|l|l|}
\hline & M1 & M2 & M3 & M4 & M5 & M6 & M7 & M8 & M9 & M10 & M11 & M12 \\
\hline Turkey & 0,023 & 0,037 & 0,062 & 0,037 & 0,027 & 0,027 & 0,093 & 0,047 & 0,021 & 0,031 & 0,037 & 0,031 \\
\hline Germany & 0,040 & 0,032 & 0,053 & 0,020 & 0,027 & 0,040 & 0,040 & 0,023 & 0,032 & 0,053 & 0,053 & 0,080 \\
\hline & M13 & M14 & M15 & M16 & M17 & M18 & M19 & M20 & M21 & M22 & M23 & \\
\hline Turkey & 0,03 & 0,09 & 0,02 & 0,04 & 0,03 & 0,19 & 0,02 & 0,03 & 0,03 & 0,03 & 0,02 & \\
\hline Germany & 0,02 & 0,02 & 0,02 & 0,08 & 0,03 & 0,03 & 0,02 & 0,16 & 0,02 & 0,08 & 0,02 & \\
\hline
\end{tabular}

After the item weights were determined, the lowest and highest value order was assigned to assign the scores according to the values of Saaty (2008), and these scores were assigned 1 to 9 points. When these assignments are made, equal interval method is used by calculating metric structures between criterion values.

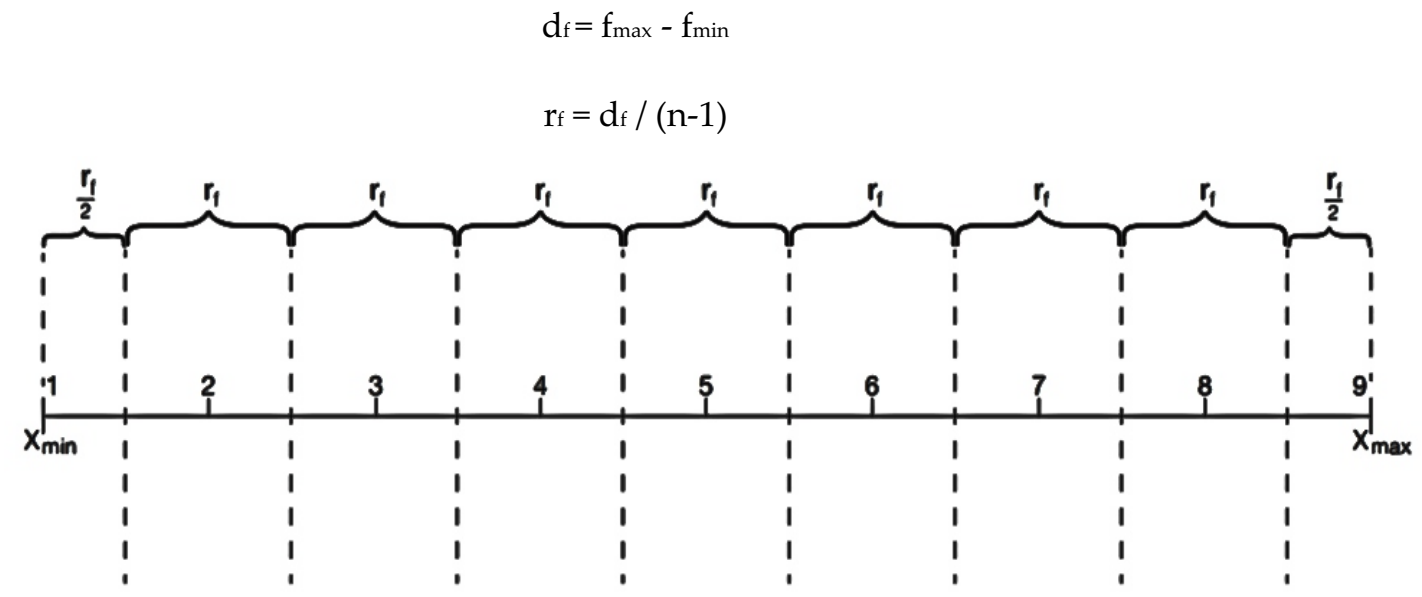

Figure 2. Adjustment to Saaty Scale

The mean values of the factors were obtained by taking the geometric mean of the respondents' answers so that the answers given in the 23-item questionnaire could be collected in 7 factors. 
V. Yüncü - C. Koparal 11/2 (2019) 1044-1056

Table 4. Adjusted scores for Turkey and Germany

\begin{tabular}{|c|c|c|c|c|c|c|c|}
\hline Turkey & $\begin{array}{c}\text { F1 } \\
\text { Product } \\
\mathbf{s}\end{array}$ & $\begin{array}{c}\text { F2 } \\
\text { Innovatio } \\
\mathbf{n}\end{array}$ & $\begin{array}{c}\text { F3 } \\
\text { Workplac } \\
\mathbf{e}\end{array}$ & $\begin{array}{c}\text { F4 } \\
\text { Governanc } \\
\mathbf{e}\end{array}$ & $\begin{array}{c}\mathbf{F 5} \\
\text { Citizenshi } \\
\mathbf{p}\end{array}$ & $\begin{array}{c}\text { F6 } \\
\text { Leadershi } \\
\mathbf{p}\end{array}$ & $\begin{array}{c}\text { F7 } \\
\text { Performanc } \\
\mathbf{e}\end{array}$ \\
\hline $\begin{array}{c}\text { Mean } \\
\text { Values }\end{array}$ & 5,257 & 4,982 & 5,158 & 4,997 & 5,057 & 5,132 & 4,850 \\
\hline $\begin{array}{c}\text { Saaty } \\
\text { Values }\end{array}$ & 9 & 4 & 7 & 4 & 5 & 7 & 1 \\
\hline $\begin{array}{c}\text { German } \\
\mathbf{y}\end{array}$ & $\begin{array}{c}\text { F1 } \\
\text { Product } \\
\mathbf{s}\end{array}$ & $\begin{array}{c}\text { F2 } \\
\text { Innovatio } \\
\mathbf{n}\end{array}$ & $\begin{array}{c}\text { F3 } \\
\text { Workplac } \\
\mathbf{e}\end{array}$ & $\begin{array}{c}\text { Governanc } \\
\mathbf{e}\end{array}$ & $\begin{array}{c}\text { Citizenshi } \\
\mathbf{p}\end{array}$ & $\begin{array}{c}\text { Leadershi } \\
\mathbf{p}\end{array}$ & $\begin{array}{c}\text { Performanc } \\
\mathbf{e}\end{array}$ \\
\hline $\begin{array}{c}\text { Mean } \\
\text { Values }\end{array}$ & 5,158 & 4,761 & 6,016 & 4,654 & 4,943 & 5,395 & 4,295 \\
\hline $\begin{array}{c}\text { Saaty } \\
\text { Values }\end{array}$ & 5 & 3 & 9 & 3 & 4 & 6 & 1 \\
\hline
\end{tabular}

Factor values created via the adjustment scale are given in table 4 . Since the ruler is designed to assign a value to a certain range as shown in figure 2 , multiple factors can have the same values. This structure, indeed, gives flexibility in the conversion of the data. For instance, the 2 nd factor and the 4 th factor values are 4 in both cases adapted to Saaty (2008) scale but the actual values are 4,982 for Factor 2 and 4,997 for Factor 4 . Due to the dynamic structure formed by this system, all factor loads are assigned to the values of Saaty (2008).

\subsection{Analysis Of Factors Via AHP}

Table 5. Comparison matrix of factors

\begin{tabular}{|c|c|c|c|c|c|c|c|}
\hline Turkey & F1 & F2 & F3 & F4 & F5 & F6 & F7 \\
\hline F1 & 1,000 & 0,444 & 0,778 & 0,444 & 0,556 & 0,778 & 0,111 \\
\hline F2 & 2,250 & 1,000 & 1,750 & 1,000 & 1,250 & 1,750 & 0,250 \\
\hline F3 & 1,286 & 0,571 & 1,000 & 0,571 & 0,714 & 1,000 & 0,143 \\
\hline F4 & 2,250 & 1,000 & 1,750 & 1,000 & 1,250 & 1,750 & 0,250 \\
\hline F5 & 1,800 & 0,800 & 1,400 & 0,800 & 1,000 & 1,400 & 0,200 \\
\hline F6 & 1,286 & 0,571 & 1,000 & 0,571 & 0,714 & 1,000 & 0,143 \\
\hline F7 & 9,000 & 4,000 & 7,000 & 4,000 & 5,000 & 7,000 & 1,000 \\
\hline Germany & F1 & F2 & F3 & F4 & F5 & F6 & F7 \\
\hline F1 & 1,000 & 0,600 & 1,800 & 0,600 & 0,800 & 1,200 & 0,200 \\
\hline F2 & 1,667 & 1,000 & 3,000 & 1,000 & 1,333 & 2,000 & 0,333 \\
\hline F3 & 0,556 & 0,333 & 1,000 & 0,333 & 0,444 & 0,667 & 0,111 \\
\hline F4 & 1,667 & 1,000 & 3,000 & 1,000 & 1,333 & 2,000 & 0,333 \\
\hline F5 & 1,250 & 0,750 & 2,250 & 0,750 & 1,000 & 1,500 & 0,250 \\
\hline F6 & 0,833 & 0,500 & 1,500 & 0,500 & 0,667 & 1,000 & 0,167 \\
\hline F7 & 5,000 & 3,000 & 9,000 & 3,000 & 4,000 & 6,000 & 1,000 \\
\hline
\end{tabular}

The situation in which we can see the advantages of the factors against each other is given in table 5. Saaty (2008) scores assigned to the factors show the superiority of each factor against one another. Therefore, the values forming the primary diagonal are calculated as 1.00 which is called power balance. Although the AHP has a consistent system, the realism of the results will depend on the consistency of the decision maker's comparison between the factors. Since the number of decision makers is very high, the system could be expected to produce consistent results. At the same time within the AHP method, consistency of the comparison can be measured. The resulting Consistency Ratio (CR) provides the possibility to test the consistency of the priority vector and thus the individual comparisons between the factors. The AHP bases 
the calculation of $\mathrm{CR}$ on the comparison of the number of the factors and $\lambda$ (basic value) quotient. Hence, in order to calculate $\lambda$ first, We first derive the column vector $\mathrm{D}$ from the multiplication of comparison matrix $\mathrm{A}$ and priority vector $W$.

$$
\text { DTurkey }=\left[\begin{array}{c}
2,371 \\
0,835 \\
0,477 \\
0,835 \\
0,668 \\
0,477 \\
1,338
\end{array}\right] \quad \text { DGermany }=\left[\begin{array}{l}
0,353 \\
1,176 \\
3,454 \\
0,397 \\
0,397 \\
0,635 \\
1,588
\end{array}\right]
$$

Next, the basic value (E) for each evaluation factor is obtained from the partition of the found column vector $\mathrm{D}$ and the reciprocal elements of the column vector $\mathrm{W}$.

$$
\text { ETurkey }=\left[\begin{array}{l}
7,000 \\
7,000 \\
7,000 \\
7,000 \\
7,000 \\
7,000 \\
7,000
\end{array}\right] \quad \text { EGermany }=\left[\begin{array}{l}
7,000 \\
7,000 \\
7,000 \\
7,000 \\
7,000 \\
7,000 \\
7,000
\end{array}\right]
$$

The arithmetic mean of these values gives the basic value for comparison $(\lambda)$. CR (consistency ratio) is obtained by dividing CI (consistency indicator) by Random Indicator (RI) standard correction value shown in Table 2 . From Table 1, the value corresponding to the factor number is selected. In order to achieve consistency, it is expected that the obtained CR value is smaller than 0,10 . As a result of the operation, the CR value of the research was found as " 0 ". In this case it is possible to talk about the consistency of the results of the research.

Table 6. AHP Scores of the 23 items

\begin{tabular}{|l|c|c|c|c|c|c|c|}
\hline Turkey & $\begin{array}{l}\text { Product } \\
\mathrm{s}\end{array}$ & $\begin{array}{l}\text { Innovatio } \\
\mathrm{n}\end{array}$ & $\begin{array}{l}\text { Workplac } \\
\mathrm{e}\end{array}$ & $\begin{array}{l}\text { Governanc } \\
\mathrm{e}\end{array}$ & $\begin{array}{l}\text { Citizenshi } \\
\mathrm{p}\end{array}$ & $\begin{array}{l}\text { Leadershi } \\
\mathrm{p}\end{array}$ & $\begin{array}{l}\text { Performanc } \\
\mathrm{e}\end{array}$ \\
\hline $\begin{array}{l}\text { AHP } \\
\text { Scores }\end{array}$ & 0,201 & 0,129 & 0,131 & 0,138 & 0,152 & 0,142 & 0,107 \\
\hline Percentage & $\% 20,1$ & $\% 12,9$ & $\% 13,1$ & $\% 13,8$ & $\% 15,2$ & $\% 14,2$ & $\% 10,7$ \\
\hline Germany & $\begin{array}{l}\text { Product } \\
\mathrm{s}\end{array}$ & $\begin{array}{l}\text { Innovatio } \\
\mathrm{n}\end{array}$ & $\begin{array}{l}\text { Workplac } \\
\mathrm{e}\end{array}$ & $\begin{array}{l}\text { Governanc } \\
\mathrm{e}\end{array}$ & $\begin{array}{l}\text { Citizenshi } \\
\mathrm{p}\end{array}$ & $\begin{array}{l}\text { Leadershi } \\
\mathrm{p}\end{array}$ & $\begin{array}{l}\text { Performanc } \\
\mathrm{e}\end{array}$ \\
\hline $\begin{array}{l}\text { AHP } \\
\text { Scores }\end{array}$ & 0,122 & 0,184 & 0,205 & 0,123 & 0,129 & 0,114 & 0,123 \\
\hline Percentage & $\% 12,2$ & $\% 18,4$ & $\% 20,5$ & $\% 12,3$ & $\% 12,9$ & $\% 11,4$ & $\% 12,29$ \\
\hline
\end{tabular}

As a result of the study, the AHP scores shown in table 6 were obtained. In the sample of Turkey, products and services and performance factors come to foreground as extreme values according to the percentage of importance distributions. In Germany sample, the highest score with $20.5 \%$ belongs to the workplace factor. The other factors are innovativeness, citizenship, management, performance, products and services, and leadership factors, respectively, according to percentage distribution of importance. This result implies the rejection of the hypothesis $\mathrm{H}_{0}$. Accordingly, there is a statistically significant effect of cultural factors on reputation perception.

\subsection{Analysis Of 23 Items Of 7 Factors Via AHP}

As stated in the research model, the scale consists of 7 factors and 23 items. Following the analysis of the data and the application of the results of the research as outlined in the model section, the applicability of the scale with the smaller number of items was tested. To achieve this, an intragroup AHP was applied to the sub-items of 7 factors to determine the items with the greatest representation value within its factor. Finally, by means 
of applying an independent two sample t-test as shown below in table 7 and table 8 , it was observed that extremely close results can be achieved when these 7 items with the greatest representation values are applied instead of posing 23 items to the participants. Without doubt, this can be considered as a novel approach and a coherent model shown in figure 1 that facilitates the application of scale.

$\mu_{1}=$ AHP scores based on 7 Factors

$\mu_{2}=$ AHP scores based on intragroup items with best representation values

$\mathrm{H}_{0}$ : There is not a statistically significant difference between $\mu_{1}$ and $\mu_{2}$

$\mathrm{H}_{1}$ : There is a statistically significant difference between $\mu_{1}$ and $\mu_{2}$

Table 7. Group Statistics

\begin{tabular}{|c|c|c|c|c|c|}
\hline & Method & N & Mean & $\begin{array}{c}\text { Std. } \\
\text { Deviation }\end{array}$ & $\begin{array}{c}\text { Std. Error } \\
\text { Mean }\end{array}$ \\
\hline AHP Scores & $\mu_{1}$ & 7 &, 1429 &, 02917 &, 01103 \\
\cline { 2 - 6 } Turkey & $\mu_{2}$ & 7 &, 1429 &, 07637 &, 02887 \\
\hline $\begin{array}{c}\text { AHP Scores } \\
\text { Germany }\end{array}$ & $\mu_{1}$ & 7 &, 1429 &, 03606 &, 01363 \\
\cline { 2 - 6 } & $\mu_{2}$ & 7 &, 1429 &, 06685 &, 02527 \\
\hline
\end{tabular}

Table 8. Independent two sample t-test

\begin{tabular}{|c|c|c|c|c|c|c|c|c|c|}
\hline \multirow{3}{*}{$\begin{array}{c}\text { AHP Scores } \\
\text { Turkey }\end{array}$} & \multicolumn{2}{|c|}{$\begin{array}{l}\text { Levene's Test } \\
\text { for equality of } \\
\text { variances }\end{array}$} & \multicolumn{7}{|c|}{ t-test for Equality of Means } \\
\hline & \multirow[t]{2}{*}{$\mathrm{F}$} & \multirow[t]{2}{*}{ Sig. } & \multirow[t]{2}{*}{$t$} & \multirow[t]{2}{*}{ df } & \multirow[t]{2}{*}{$\begin{array}{l}\text { Sig. }(2- \\
\text { tailed) }\end{array}$} & \multirow[t]{2}{*}{$\begin{array}{l}\text { Mean } \\
\text { Diff }\end{array}$} & \multirow{2}{*}{$\begin{array}{l}\text { Standard } \\
\text { Error } \\
\text { Difference }\end{array}$} & \multicolumn{2}{|c|}{$\begin{array}{c}\text { 95\% Confidence } \\
\text { Interval of the } \\
\text { Difference } \\
\end{array}$} \\
\hline & & & & & & & & Lower & Upper \\
\hline $\begin{array}{c}\text { Equal variances } \\
\text { assumed }\end{array}$ & 1,78 & ,207 &, 000 & 12 & 1,000 &, 000 & 030900 &,- 06733 & ,06733 \\
\hline $\begin{array}{c}\text { Equal variances } \\
\text { not assumed }\end{array}$ & & & ,000 & 7,715 & 1,000 &, 000 & ,030900 &,- 07172 & 07172 \\
\hline \multirow{3}{*}{$\begin{array}{l}\text { AHP Scores } \\
\text { Germany }\end{array}$} & \multicolumn{2}{|c|}{$\begin{array}{l}\text { Levene's Test } \\
\text { for equality of } \\
\text { variances }\end{array}$} & \multicolumn{7}{|c|}{ t-test for Equality of Means } \\
\hline & \multirow[t]{2}{*}{$\mathrm{F}$} & \multirow[t]{2}{*}{ Sig. } & \multirow[t]{2}{*}{$\mathrm{t}$} & \multirow[t]{2}{*}{ df } & \multirow[t]{2}{*}{$\begin{array}{l}\text { Sig. (2- } \\
\text { tailed) }\end{array}$} & \multirow[t]{2}{*}{$\begin{array}{l}\text { Mean } \\
\text { Diff }\end{array}$} & \multirow{2}{*}{$\begin{array}{l}\text { Standard } \\
\text { Error } \\
\text { Difference }\end{array}$} & \multicolumn{2}{|c|}{$\begin{array}{c}\text { 95\% Confidence } \\
\text { Interval of the } \\
\text { Difference }\end{array}$} \\
\hline & & & & & & & & Lower & Lower \\
\hline $\begin{array}{c}\text { Equal variances } \\
\text { assumed }\end{array}$ & 2,468 & ,142 & ,000 & 12 & 1,000 &, 000 & ,02871 &,- 06255 & ,06255 \\
\hline $\begin{array}{l}\text { Equal variances } \\
\text { not assumed }\end{array}$ & & &, 000 & 9,219 & 1,000 &, 000 & ,02871 &,- 06471 & ,06471 \\
\hline
\end{tabular}

Firstly, the assumption of equality of variances has been tested. For this, Levene's test significance value is considered. As the survey has been sustained in 95\% confidence interval or in other words, in 0.05 significance level the variances are considered equal if this value is greater than 0.05 . After this step, the first line of the analysis is valid, followed by the t-test section of the table to see if there is a statistical difference between $\mu_{1}$ and $\mu_{2}$. More clearly, If the value of t-test significance value in first line of the table is less than $0.05 \mathrm{H}_{0}$ is accepted, otherwise $\mathrm{H}_{0}$ is rejected. In our survey, this value has appeared to be 0 , which means that $\mathrm{H}_{0}$ is accepted and that there is no statistical difference between the two results. In conclusion, the acceptance of the hypothesis $\mathrm{H}_{0}$ suggests that future research could be done with 7 items instead of 23 items of the scale. 
V. Yüncü - C. Koparal 11/2 (2019) 1044-1056

Table 9. Intragroup AHP item based scores

\begin{tabular}{|c|c|c|c|}
\hline & & Turkey & Germany \\
\hline \multirow{4}{*}{ F1 } & M1 & 0,673 & 0,643 \\
\hline & M9 & 0,075 & 0,214 \\
\hline & M15 & 0,168 & 0,071 \\
\hline & M19 & 0,084 & 0,071 \\
\hline \multirow{3}{*}{ F2 } & M2 & 0,087 & 0,089 \\
\hline & M13 & 0,783 & 0,114 \\
\hline & M20 & 0,130 & 0,797 \\
\hline \multirow{3}{*}{ F3 } & $\mathrm{M} 4$ & 0,184 & 0,692 \\
\hline & M11 & 0,735 & 0,231 \\
\hline & M21 & 0,082 & 0,077 \\
\hline \multirow{3}{*}{ F4 } & M6 & 0,153 & 0,231 \\
\hline & M16 & 0,763 & 0,692 \\
\hline & M23 & 0,085 & 0,077 \\
\hline \multirow{3}{*}{ F5 } & M5 & 0,090 & 0,089 \\
\hline & M10 & 0,809 & 0,797 \\
\hline & M17 & 0,101 & 0,114 \\
\hline \multirow{4}{*}{ F6 } & M3 & 0,134 & 0,552 \\
\hline & M7 & 0,537 & 0,276 \\
\hline & M14 & 0,060 & 0,061 \\
\hline & M18 & 0,269 & 0,110 \\
\hline \multirow{3}{*}{ F7 } & M8 & 0,621 & 0,069 \\
\hline & M12 & 0,310 & 0,310 \\
\hline & M22 & 0,069 & 0,621 \\
\hline
\end{tabular}

As can be seen in Table 9, when we perform the research based on 7 items rather than 23 items, very close results are obtained as no difference could be observed in the order of importance based on factors. In addition, the comparative scores obtained from the intragroup AHP and factor based AHP are also given in Table 10.

Table 10. Comperative AHP Scores

\begin{tabular}{|c|c|c|c|c|c|c|c|}
\hline Turkey & Products & Innovation & Workplace & Governance & Citizenship & Leadership & Performance \\
\hline $\begin{array}{l}\text { Factor } \\
\text { based } \\
\text { scores }\end{array}$ & 0,201 & 0,129 & 0,131 & 0,138 & 0,152 & 0,142 & 0,107 \\
\hline $\begin{array}{c}\text { Item } \\
\text { based } \\
\text { scores }\end{array}$ & 0,314 & 0,109 & 0,111 & 0,110 & 0,131 & 0,128 & 0,097 \\
\hline Germany & Products & Innovation & Workplace & Governance & Citizenship & Leadership & Performance \\
\hline $\begin{array}{l}\text { Factor } \\
\text { based } \\
\text { scores }\end{array}$ & 0,122 & 0,184 & 0,205 & 0,123 & 0,129 & 0,114 & 0,123 \\
\hline $\begin{array}{c}\text { Item } \\
\text { based } \\
\text { scores }\end{array}$ & 0,108 & 0,197 & 0,273 & 0,109 & 0,110 & 0,095 & 0,108 \\
\hline
\end{tabular}




\section{Conclusions and Discussions}

As is seen, this study aims to bring a new and a cross-cultural perspective to the way organizational reputation is managed for today's managers who, as Huber (2017) asserts, largely recognize the importance of cultural differences as national culture strongly affects reputation perceptions across nations. Indeed, she further indicates that "managers must be interested in which cultural value approaches and particular cultural dimensions are of major importance, in explaining varying reputation perceptions across nations". Hence, the most basic features of this research that differentiate it from the previous researches are that, first it has been conducted on two different cultural background which are relatively divergent and second, instead of putting forward an alternative way to score reputation, which is frequently repeated in the literature, this survey focuses on the factors and their order of importance for consumers and the superiority of the mentioned factors to each other in detail. Thus, two divergent cultural groups have been compared in terms of their perception of reputation and found out the basic variables that shape this perception for each group. Accordingly, the product and services factor has the highest score in Turkey sample is with a percentage of $20.1 \%$. Other factors following this factor based on order of importance attributed are citizenship, leadership, governance, workplace, innovativeness and performance factors respectively. In the context of this sample, products and services and performance factors stand out as the two extreme values according to the average of the percentage significance distributions, which means that the criteria that the participants in this sample value the most are directly related to the product itself. Accordingly, the quality of the product or service, the ability to meet the consumer's needs, the stand behind the products or services of the enterprises, and the services provided to the customers after the sale constitute the most important part of the consumer's overall sense of reputation. On the other hand, the highest score of $20.5 \%$ in Germany sample belongs to the workplace factor. Accordingly, participants appear to have an employee-focused approach. Fair treatment of employees, fair rewarding, offering equal opportunities and finally valuing the health and welfare of employees is the most important part of the overall perception of reputation of the participants in this group. Also, Among the factors, the second factor innovation has the highest importance with a percentage of $18.4 \%$. This means that the participants in the sample considerably value the change, the pace of change and the pioneering of new products or services. Other factors are citizenship, management, performance, products and services in terms of percentage of importance, and leadership factors observed to have the lowest prevalence of $11.4 \%$ respectively. In addition to the researches available in the literature, this study, conducted with cultural context awareness, was conducted from the perspective of consumers who will make the final purchase decision, who are also the most important stakeholder group of the business. Hence, within the scope of reputation management context, it could be regarded as an important and novel step filling the gap that existing criticisms that consumers have not been directly addressed in academic surveys yet. The results of the research are also laying the groundwork for new and original research subjects for future studies. For example, it is considered that the literature review of the causes of cultural differences identified in the research or the examination of the effects of demographic variables on the corporate reputation perception may contribute significantly. In addition, it is concluded that the scale could be applied using merely 7 items instead of 23 items, which will provide considerable convenience in terms of time and cost for future research. 


\section{References}

Alonso, J.A. and Lamata, M.T. (2006). Consistency in AHP: A New Approach. International Journal of Uncertainty, Fuzziness and Knowledge-Based Systems Vol. 14, No. $4 . \quad 445-459$. https://doi.org/10.1142/S0218488506004114

Altunışık, R. (2008). Anketlerde veri kalitesinin iyileştirilmesi için öntest yöntemleri, Pazarlama ve Pazarlama Araştırmaları Dergisi, 2, 1-17.

Chahal, H., Kumari, A. (2014). Measurement, Validation and Factor Structure of Corporate Reputation in Banking Sector of India, Global Business Review, 15(2) 237-261. doi.org/10.1177/0972150914523570

Connelly, B. L.; Trevis, S.C.; Ireland, R. D.; Reutzel, C. R. (2011). Signaling Theory: A Review and Assessment. Journal of Management Vol. 37 No. 1, January 2011 39-67. https://doi.org/10.1177/0149206310388419

Corsino, M. and Passarelli, M. (2009), The competitive advantage of business units: Evidence from the integrated circuit industry. European Management Review, 6: 182-194. doi:10.1057/emr.2009.15

Dane K. Peterson, (2018) "Enhancing corporate reputation through corporate philanthropy", Journal of Strategy and Management, Vol. 11 Issue: 1, pp.18-32, https://doi.org/10.1108/JSMA-10-2016-0068

De Roeck, K., Maon, F. and Lejeune, C. (2013), Taking Up the Challenge of Corporate Branding: An Integrative Framework. European Management Review, 10: 137-151. doi:10.1111/emre.12010

Deb, P. (2013), Signaling Type and Post-IPO Performance. European Management Review, 10: 99-116. doi:10.1111/emre.12012

Deephouse, D.L. and Carter, S. M. (2005). An examination of differences between organizational legitimacy and organizational reputation. Journal of Management Studies, 42(2), 329-360.

Delgado-Márquez, B. L., and Pedauga, L. E. (2017) Environmental Behavior and MNEs: A Strategy Pulled by Stakeholder Engagement. Business Strategy and the Environment., 26: 927-939. doi: 10.1002/bse.1955.

DiMaggio, P.J. and Powell, W.W. (1991). Introduction in The New Institutionalism in Organizational Analysis. (Walter W. Powell and Paul J. DiMaggio), The University of Chicago Press, Chicago, 1-38

Dowling, G. R. (2016) Defining and Measuring Corporate Reputations. European Management Review, 13: 207-223. doi: 10.1111/emre.12081.

Dowling, G. R., and Gardberg, N. A. (2012). Keeping score: the challenges of measuring corporate reputation. The Oxford Handbook of Corporate Reputation, 34.

Duman, Ş. (2012). Kurumsal Kuram Yaklaşımı ile Örgütsel Değişimi Anlamaya Yönelik Bir İnceleme. Journal of Business Economics and Political Science Vol: 1 No: 1, 9-23

Fombrun, C. J.; Ponzi, L. J.; Newburry, W. (2015). Stakeholder Tracking and Analysis: The RepTrak® System for Measuring Corporate Reputation. Corporate Reputation Rewiew, Volume 18, Number 1. https://doi.org/10 1057/crr.2014.21

Gottschalk, P. (2011). Corporate Social Responsibility, Governance and Corporate Reputation. Singapore: World Scientific Publishing Co. Pte. Ltd.

Göksu, A. and Güngör, İ. (2008). Bulanık AHP ve Üniversite Tercih Sıralamasıda Uygulanması, Süleyman Demirel Üniversitesi Iktisadi ve Idari Bilimler Fakültesi Dergisi, C.13, S.3 s.1-26.

Groenland, E. A. G. (2002). Qualitative research to validate the RQ-dimensions. Corporate Reputation Review, 4(4), 308. https://doi.org/10.1057/palgrave.crr.1540152

Hatch, M. J. Schultz, M. (2003). Bringing the corporation into corporate branding. European Journal of Marketing, 3(7), $1041-1064$.

Huber, Cathrin. (2018). Study 3: Corporate Reputation Perceptions Across Nations: The Role of National Culture. 10.1007/978-3-658-19764-3_4. 
Inglis, R, Morley, C and Sammut, P 2006, 'Corporate reputation and organisational performance: an Australian study', Managerial Auditing Journal, vol. 21, no. 9, pp. 934-947.

Lange, D.; Lee, P. M.; Dai, Y. (2011). Organizational Reputation: A Review. Journal of Management, Vol. 37 No. 1, January 153-184. https://doi.org/10.1177/0149206310390963

Omar, M., Williams, R.L. and Lingelbach, D. (2009). Global brand market-entry to manage corporate reputation", Journal of Product and Brand Management, Vol. 18 No. 3, s. 177-87. https://doi.org/10.1108/10610420910957807

Patel, T. (2017) Multiparadigmatic Studies of Culture: Needs, Challenges, and Recommendations for Management Scholars. European Management Review, 14: 83-100. doi: 10.1111/emre.12089.

Radomir, L.; laiaş, I., Nistor, V. (2014). Corporate reputation, image and identity: Conceptual approaches. International conference - marketing - from information to decision, 7th Edition. 219-229.

Saaty, T. L. (2008). Decision making with the analytic hierarchy process, Int. J. Services Sciences, Vol. 1, No. 1 s. 83-98

Sargut A. S. and Özen Ş. (2010). Örgüt Kuramları. İmge

Sirsly, A. T. and Lvina, E. (2016). From Doing Good to Looking Even Better: The Dynamics of CSR and Reputation. Business and Society, 1-33. https://doi.org/10.1177/0007650315627996

Spence, A. M., 1973, “Job market signaling”. Quarterly Journal of Economics, 87: 355-379.

Sumer, H. And Pernsteiner, H. (2014). İtibar Yönetimi, İstanbul: Beta

Walker, K. (2010). A Systematic Review of the Corporate Reputation Literature: Definition, Measurement, and Theory. Corporate Reputation Review. Vol. 12 N. 4. https://doi.org/10.1057/crr.2009.26

Zarkada, A.K. and Polydorou, C. (2013). You Might Be Reputable But Are You "Liked"? Orchestrating Corporate Reputation Co-Creation on Facebook. Social Media in Strategic Management. (Olivas-Luja M.R. and Bondarauk T.) Bingley: Emerald Group S. 8. 